\title{
Antimicrobial activity of leaf extracts of Euphorbia paralias L. and Melilotus sulcatus Desf. against some pathogenic microorganisms
}

\author{
Miloud M. Miloud ${ }^{1 *}$, Najma A. Senussi² \\ 'Department of Botany, Faculty of Science, Benghazi University (Al-abyar Branch), Libya, '2Department of Botany, \\ Faculty of Science, Ajdabiya University, Libya
}

Received: December 14, 2020 Revised: February 8, 2021 Accepted: February 11, 2021 Published: February 26, 2021

*Corresponding Author: Miloud M. Miloud, Miloud.elagaily@uob.edu.ly

\begin{abstract}
The present study was aimed to investigate the antimicrobial potential of leaf extracts of Euphorbia paralias and Melilotus sulcatus against four bacterial species Staphylococcus aureus, Pseudomonas aeruginosa, Escherichia coli and Klebsiella sp. and two fungal species Asperigillus niger and Aspergillus flavus. The agar well diffusion assay was used to evaluate the antimicrobial activity. The effect of these extracts was most effective against the bacterial species compared to the fungal species at a used concentration $(100 \mathrm{mg} / \mathrm{ml})$. Methanolic extracts of selected plants displayed good antimicrobial activity against all tested microorganisms species, while, no activity for aqueous extracts against tested fungal species. Methanolic extracts were the most effective plant extracts against all tested bacterial species, with MIC and MBC reached 6.2 and $12.5 \mathrm{mg} / \mathrm{ml}$, except Klebsiella sp. which was less sensitive to M. sulcatus methanolic extract and its MIC and MBC reached 12.5 and $25 \mathrm{mg} / \mathrm{ml}$, respectively. These plant extracts which proved to be potentially effective can be used as bioactive agents to control microorganisms caused for diseases and they can be used naturally in the human and veterinary healthcare systems.
\end{abstract}

KEYWORDS: Euphorbia paralias L., Melilotus sulcatus Desf., Antimicrobial activity, agar well diffusion assay, MIC, MBC

\section{INTRODUCTION}

The pathogenic microorganism species have been increased their resistance to many of the chemically synthesized antibiotics that were previously used to resist them. In 2011, the WHO called for increased research on new drugs as antibiotic resistance increases dramatically (Abedini et al., 2013; Abreu et al., 2012). The use of plant extracts and phytochemicals, both with known antimicrobial properties, can be of great significance in therapeutic treatments. In the last few years, a number of studies have been conducted in different countries to prove such efficiency (Izzo et al., 1995; Schapoval et al., 1994; Kubo et al., 1993). Many plants have been used because of their antimicrobial traits, which are due to compounds synthesized in the secondary metabolism of the plant. These products are known by their active substances, for example, the phenolic compounds which are part of the essential oils (Janssen et al., 1987). Euphorbia paralias L. (E. paralias), belongs to the family Euphorbiaceae. It is a perennial herb. The stem and leaves produce a white or milky juice when cut. This species distributed in coastal areas of Europe \& North Africa. A species, growing in the sand along the coastal area of Libya, easily recognized by its small densely compact appressed leaves (Jafri \& El-Gadi, 1982). The Euphorbia includes many species that containing tannins, terpenes, anthocyanins, alkaloids, steroids like ßsito-sterol, ß-amyrin and glycosides (Scalbert, 1991; Gupta \& Gupta, 2019), it includes also many species that are used medically in the treatment of many diseases such as pulmonary tuberculosis, ascites, edema, asthma, stomach, liver and uterine cancer, It also treats worm infestations in children and for gonorrhea, jaundice, pimples, digestive problems (Kirtikar \& Basu, 1991; Feng et al., 2010).

Melilotus sulcatus Desf. (M. sulcatus) belongs to the family Fabaceae. It is an annual herb. This species distributed in the Mediterranean region "South Europe \& North Africa" (Jafri \& ElGadi, 1980). The Melilotus includes many species that contains coumarins, melilotin, phenolic acids, flavonoids, carbohydrates, glycosides, saponins, volatile oils, steroids, triterpenes, tannin, alcohols, bishydroxycoumarin, choline, uric acid and many other chemical groups (Al-Snafi, 2020; Sonju et al., 2017), it includes also many species that are used medically in the treatment of osteoporosis, high blood pressure, cancer, kidney and liver

Copyright: (C) The authors. This article is open access and licensed under the terms of the Creative Commons Attribution License (http://creativecommons.org/licenses/by/4.0/) which permits unrestricted, use, distribution and reproduction in any medium, or format for any purpose, even commercially provided the work is properly cited. Attribution — You must give appropriate credit, provide a link to the license, and indicate if changes were made. 
complaints (Akhtar et al., 2016). The aim of this study is to evaluate the activity of aqueous and methanolic crude extracts of E. paralias and M. sulcatus against some pathogenic bacteria and fungi species.

\section{MATERIALS AND METHODS}

\section{Collection and Preparation of Plant Samples}

Fresh samples were collected from the leaves of the selected plants in the late spring month of 2020 from the Zuwetina region, northwest of Benghazi for E. paralias and M. sulcatus from the southeast of Benghazi in Libya. The leaves were placed in plastic bags. Then leaves were washed gently under tap water to remove the dust and left in the air under shade to dry for 2 weeks, then cut into small pieces and crushed into powder using an electric blender, transferred into a glass container, and preserved until the extraction procedure was performed in the laboratory.

\section{Preparation of Extracts}

According to the method of Mohammadi et al., (2015), with minor modifications, $50 \mathrm{gm}$ of the powder of Euphorbia paralias and Melilotus sulcatus were filled in the thimble and extracted successively with $300 \mathrm{ml}$ each of sterile distilled water and methanol using a Soxhlet apparatus for 24 hours. All the extracts were evaporated using a rotary evaporator. At last, $2.3 \mathrm{~g}$ of dried extracts were obtained, all the extracts were dissolved in dimethyl sulfoxide (DMSO). One concentration of extracts was prepared, which is $100 \mathrm{mg} / \mathrm{ml}$, and stored at $4{ }^{\circ} \mathrm{C}$ in airtight bottles until further use.

\section{Test Microorganisms}

Bacterial species were obtained from the microbiology laboratory of Benghazi Medical Centre (BMC). Fungal species were obtained from the Botany Department, Benghazi University, Al-Abyar branch. In total, six microorganisms, four bacterial species: S. aureus, P. aeruginosa, E. coli and Klebsiella sp. and two fungal species: A. niger and A. flavus. The bacterial species were maintained on nutrient agar slants and the fungal species maintained on Potato dextrose agar slants at $4{ }^{\circ} \mathrm{C}$.

\section{Preparation of Culture Media}

Mueller Hinton Agar (MHA) and Potato Dextrose Agar (PDA) media were prepared by suspending $38 \mathrm{~g}$ and $39.1 \mathrm{~g}$ in $1000 \mathrm{ml}$ of distilled water. The media was sterilized by autoclaving at $15 \mathrm{lbs}$ pressure $\left(121^{\circ} \mathrm{C}\right)$ for 15 minutes. Cool to $45-50{ }^{\circ} \mathrm{C}$, then pour into sterile Petri plates.

\section{Preparation of the Microbial Suspension}

Bacteria stock cultures (S. aureus, P. aeruginosa, E. coli, and Klebsiella sp.) were sub-cultured onto Nutrient Agar (NA) plates and incubated overnight at $37^{\circ} \mathrm{C}$ (bacterial cultures are 24 hours old). The next day, three to four discrete bacterial colonies with similar morphology were inoculated into $10 \mathrm{ml}$ sterile Mueller Hinton broth (MHB) and incubated overnight at $37^{\circ} \mathrm{C}$. The overnight bacterial suspensions were adjusted to $0.5 \mathrm{McF}$ arland Standard with sterile MHB broth, approximately $1.5 \times 10^{6} \mathrm{cell} / \mathrm{ml}$. To aid comparison, the adjustment of bacterial suspensions to the density of the $0.5 \mathrm{McF}$ arland Standard was done against a white background with contrasting black lines (Teh et al., 2017).

The fungal inoculum (spores) was prepared according to the method of Surapuram et al., (2014) with some modification, by suspending five representative colonies, obtained from fresh, mature ( 3 to 7 days-old) cultures grown at $27^{\circ} \mathrm{C}$ on PDA medium, in potato dextrose broth (PDB). Then the inoculum was adjusted to $0.5 \mathrm{McF}$ arland standard, approximately $1-5 \times 10^{6}$ spores $/ \mathrm{ml}$, by measuring the absorbance in a spectrophotometer at a wavelength of $625 \mathrm{~nm}$.

\section{Assay for Antimicrobial Activity}

The aqueous and methanolic crude extracts were tested against four bacterial species and two fungal species by MHA medium and PDA medium. This study was carried out using the agar well diffusion assay (Athanassiadis et al., 2009). Tetracycline and Fluconazole were used as the standard antibacterial and antifungal agents. The media was poured into the sterile Petri plates and allowed to solidify. The microbial suspension of each test was evenly spread over the media by sterile cotton swabs. The plates have been kept to dry and a sterile cork borer $(6 \mathrm{~mm}$ in diameter) was then used to punch wells (four wells) in the agar media. Subsequently, wells were filled with $100 \mu$ l of each extract at a concentration of $100 \mathrm{mg} / \mathrm{ml}$ and allowed to diffuse at room temperature for 1 hour, then the plates were placed in an incubator at $37^{\circ} \mathrm{C}$ for 24 hours in the case of bacteria and at $27^{\circ} \mathrm{C}$ for $48-72$ hours in the case of fungi. The DMSO solvent was used as a negative control. The resulting diameters of inhibition zones were measured using a ruler in millimeters. The experiment was performed in triplicate for each tested microorganism and plant extract, the mean zone of inhibition was calculated for each crude extract and standard antibiotic.

\section{Determination of Minimum Inhibitory Concentration (MIC) and Minimum Bactericidal Concentrations (MBC) of the Effective Plant's Extract}

The MIC test was prepared according to the method of Mostafa et al., (2018), with some modifications. The MIC is defined as the lowest concentration of the antimicrobial agent that completely inhibits visible growth as judged by the naked eye, disregarding a single colony. The most effective plant extracts which exhibiting a strong antimicrobial activity at $100 \mathrm{mg} / \mathrm{ml}$ were tested to determine their MIC using a well diffusion assay and evaluate their efficiency in controlling bacterial species causing diseases. Different concentrations of the effective plant extracts (3.1, $6.2,12.5,25,50$, and $100 \mathrm{mg} / \mathrm{ml})$. A sterile cork borer $(6 \mathrm{~mm}$ in diameter) was then used to punch wells (six wells) in the seeded Mueller-Hilton agar (MHA) with bacterial suspensions of the pathogenic species. Subsequently, wells were filled with $100 \mu l$ of each various concentrations of the effective plant extracts and 
allowed to diffuse at room temperature for 1 hour then the plates were incubated in the incubator at $37^{\circ} \mathrm{C}$ for $24 \mathrm{~h}$. The zones of inhibition were measured by a ruler in millimeters. While, the $\mathrm{MBC}$ is the concentration that causes growth inhibition by $\% 99.9$, and this was confirmed by taking a swab from the zones of inhibition and cultivate it on MHA medium again to make sure the bacteria are killed. The concentration of the plant extract that did not show any bacterial growth on the freshly inoculated MHA medium was determined as the MBC.

\section{RESULTS AND DISCUSSION}

The obtained results through this study were recorded in (Table 1 and shown in Figures 1-3). The antimicrobial activity experiments were carried out using the concentration of $100 \mathrm{mg} / \mathrm{ml}$ obtained by dissolving the aqueous and methanolic crude extracts in DMSO solvent. The antimicrobial activity was tested against four bacteria and two fungi species. Tetracycline and Fluconazole were used as a positive controls for the antibacterial and antifungal assays, respectively, the DMSO solvent was used as a negative control. Through obtained results, the effect of the E. paralias and M. sulcatus extracts was most effective against the bacterial species, compared to the fungal species, especially methanolic extracts exhibited a clear inhibitory effect against all tested microorganisms species and order of inhibition was found to be $S$. aureus $>$ P. aeruginosa $>$ E. coli $>$ Klebsiella $s p$. $>$ fungal species. While aqueous extracts did not show any activity against the fungal species.

Table 1: Inhibition Zones diameter of E.paralias and M.sulcatus extracts against tested microorganisms species

\begin{tabular}{|c|c|c|c|c|c|c|c|c|}
\hline \multirow{4}{*}{$\begin{array}{l}\text { Microorganisms } \\
\\
\text { No. } \\
\end{array}$} & \multicolumn{8}{|c|}{ The zone of inhibition is measured in millimeter } \\
\hline & \multicolumn{8}{|c|}{ Concentration $100 \mathrm{mg} / \mathrm{ml}$} \\
\hline & & & \multicolumn{2}{|c|}{ Bacterial species } & \multicolumn{4}{|c|}{ Fungal species } \\
\hline & \multicolumn{2}{|c|}{ Plant extracts } & S. aureus & $P$. aeruginosa & E. coli & Klebsiella sp. & A. niger & A. flavus \\
\hline \multirow[t]{2}{*}{1} & E. paralias & Aqueous & 12 & 10 & 10 & $\mathrm{R}$ & $\mathrm{R}$ & $\mathrm{R}$ \\
\hline & & Methanol & 16 & 15 & 13 & 13 & 9 & 9 \\
\hline \multirow[t]{2}{*}{2} & M. sulcatus & Aqueous & 12 & 9 & 9 & $\mathrm{R}$ & $\mathrm{R}$ & $\mathrm{R}$ \\
\hline & & Methanol & 15 & 14 & 12 & 10 & 9 & 9 \\
\hline 3 & $\begin{array}{l}\mathrm{C}^{+} \text {Tetracycli } \\
\text { *Fluconazol }\end{array}$ & $\begin{array}{l}\text { Antibacterial } \\
\text { ntifungal }\end{array}$ & 15 & 14 & 13 & 13 & *14 & ${ }^{*} 14$ \\
\hline 4 & C- (DMSO) & & $\mathrm{R}$ & $\mathrm{R}$ & $\mathrm{R}$ & $\mathrm{R}$ & $\mathrm{R}$ & $\mathrm{R}$ \\
\hline
\end{tabular}

$\mathrm{C}^{+}$: Positive control, C*: Negative control, R: Resistant
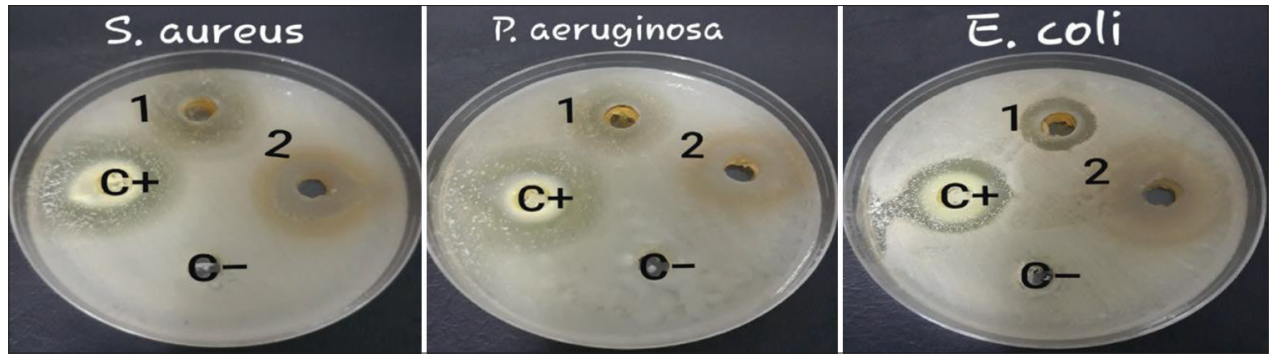

Figure 1: Effect of the aqueous extracts of 1- E. paralias and 2- M. sulcatus on bacterial species at $100 \mathrm{mg} / \mathrm{ml}$ concentration, compared with a positive and negative controls.
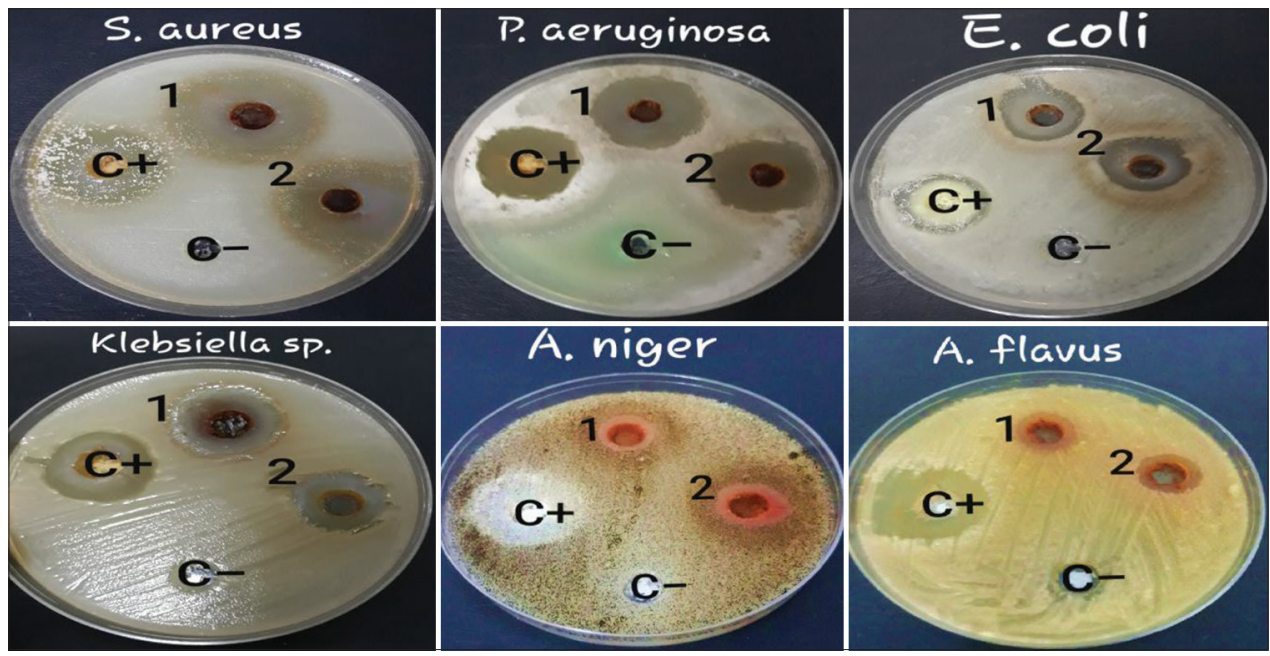

Figure 2: Effect of the methanolic extracts of 1- E. paralias and 2- M. sulcatus on microorganisms species at $100 \mathrm{mg} / \mathrm{ml}$ concentration, compared with a positive and negative controls 
By comparing the obtained results from these extracts of both plants with positive controls (Tetracycline and Fluconazole), the results of Tetracycline were fairly closed. Whereas, the results of Fluconazole have a higher effect than extracts.

The results listed in (Table 1) exhibited that the methanolic extracts were the most effective extracts and showed a good

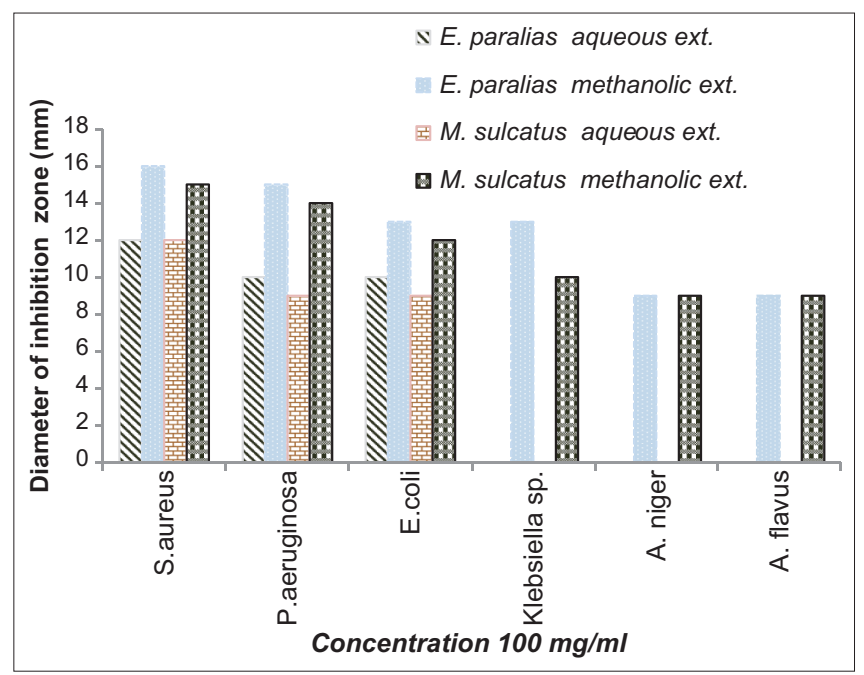

Figure 3: Effect of selected plant extracts on pathogenic microorganisms species.
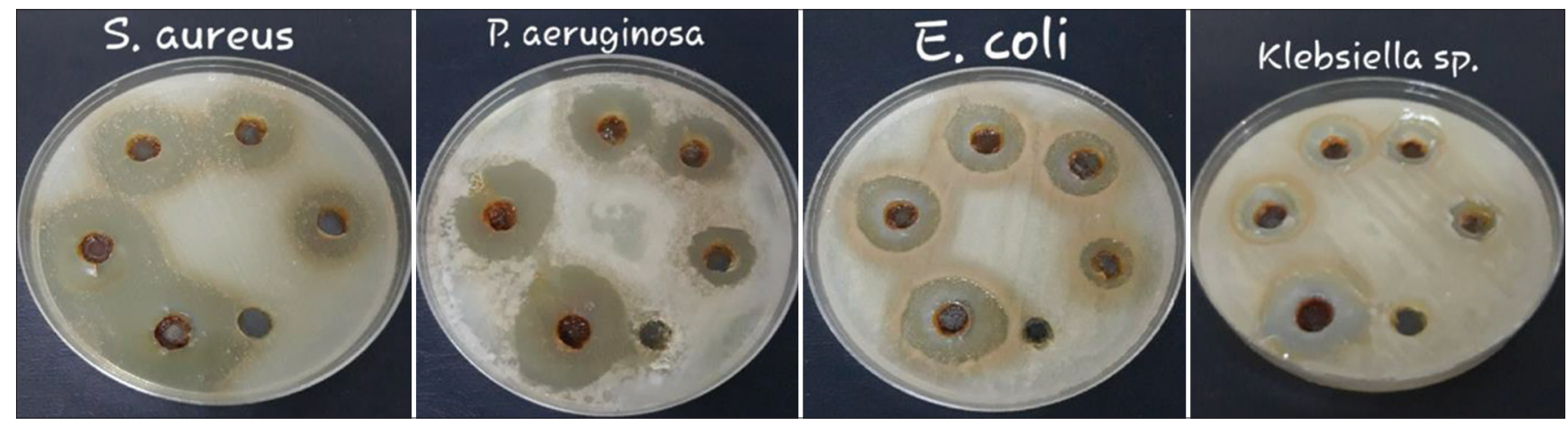

Figure 4: MIC of the methanolic extract of $E$. paralias against bacterial species at 3.1, 6.25, 12.5, 25, 50 and100 mg/ml concentrations, respectively (from right to left).

Table 2: MIC of the methanolic extract against pathogenic bacterial species

\begin{tabular}{|c|c|c|c|c|c|c|}
\hline \multirow[t]{3}{*}{ No. } & \multirow[t]{3}{*}{ Plant species } & \multicolumn{5}{|c|}{ The zone of inhibition is measured in millimeter } \\
\hline & & \multicolumn{5}{|c|}{ Bacterial species } \\
\hline & & Concentrations in $\mathrm{mg} / \mathrm{ml}$ & S. aureus & P. aeruginosa & E. coli & Klebsiella sp. \\
\hline \multirow[t]{6}{*}{1} & E. paralias & 3.1 & $\mathrm{R}$ & $\mathrm{R}$ & $\mathrm{R}$ & $\mathrm{R}$ \\
\hline & & 6.2 & 11 & 9 & 8 & 7 \\
\hline & & 12.5 & 12 & 10 & 10 & 9 \\
\hline & & 25 & 13 & 11 & 10 & 10 \\
\hline & & 50 & 15 & 14 & 12 & 11 \\
\hline & & 100 & 16 & 15 & 13 & 13 \\
\hline \multirow[t]{6}{*}{2} & M. sulcatus & 3.1 & $\mathrm{R}$ & $\mathrm{R}$ & $\mathrm{R}$ & $\mathrm{R}$ \\
\hline & & 6.2 & 10 & 10 & 7 & $\mathrm{R}$ \\
\hline & & 12.5 & 11 & 11 & 9 & 7 \\
\hline & & 25 & 13 & 11 & 10 & 8 \\
\hline & & 50 & 13 & 13 & 12 & 9 \\
\hline & & 100 & 15 & 14 & 12 & 10 \\
\hline
\end{tabular}

R: Resistant 

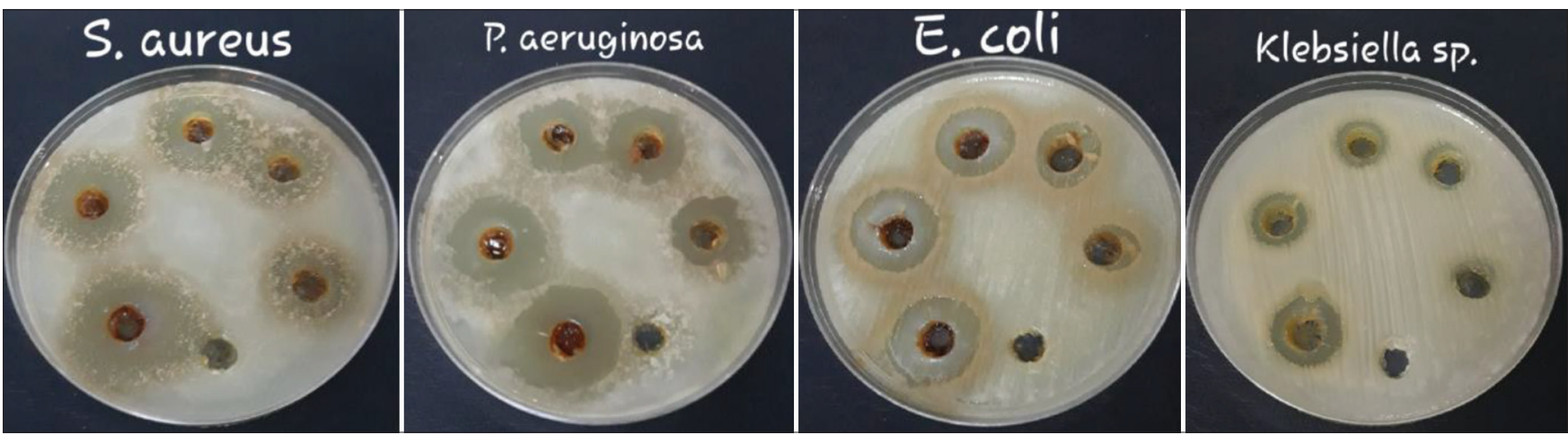

Figure 5: MIC of the methanolic extract of $M$. sulcatus against bacterial species at $3.1,6.25,12.5,25,50$ and100 $\mathrm{mg} / \mathrm{ml}$ concentrations respectively (from right to left).

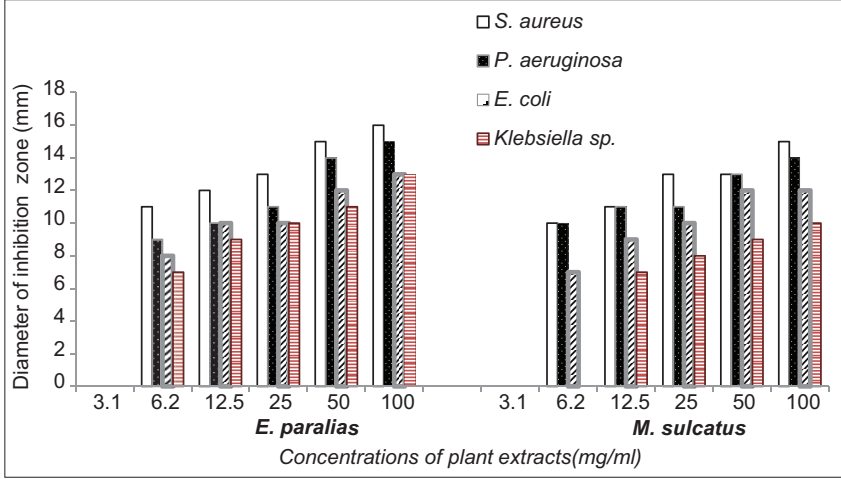

Figure 6: MIC of the methanolic extract against pathogenic bacterial species.

generations. Traditional medicine has an old history in health maintenance, as well as to prevent, diagnose, improve or treat physical and mental illness (Dhivya \& Kalaichelvi, 2017). The agar well diffusion assay has been used in this research because it is more sensitive than the agar disc diffusion assay (Valgas et al., 2007). Many studies have shown that extracts obtained from the Euphorbia and Melilotus genera inhibit the growth of different microorganisms at various concentrations (Annapurna et al., 2004; Singh \& Kumar, 2013; Sonju et al., 2017; Sisay et al., 2019). Other studies on the species of genus Euphorbia and Melilotus have confirmed the efficacy of the methanolic extracts compared with the aqueous extracts. The methanolic extracts showed high antimicrobial activity against various pathogenic microorganisms, also, the methanolic extracts displayed larger inhibition zones against Gram-positive bacteria compared to Gram-negative bacteria (Naz et al., 2017; Lone et al., 2013; Sonju et al., 2017). The results of the present study are consistent with the above studies conducted on species belong to the selected genera in this study. In plants, alkaloids, tannins, flavonoids and many aromatic compounds or secondary metabolites which is involved in defense mechanism against invading microorganisms and various predators like herbivores and insects (Lin et al., 1999). Some researchers have indicated that plant extracts antimicrobial components (terpenoid, alkaloid and phenolic compounds) interact with enzymes and proteins of the microbial cell membrane, causing their disruption to disperse a flux of protons to the outside of the cell that causes cell death or may inhibit enzymes required for the biosynthesis of amino acids (Burt, 2004; Gill \& Holley, 2006).

\section{CONCLUSION}

The degree of antimicrobial activity may be suggested to be based on the extraction process, the type, amount of extracts and the chemical properties of the compounds. According to the results of this study on Euphorbia paralias L. and Melilotus sulcatus Desf., it can be concluded that the antimicrobial potential of these plants is confirmed and their extracts are suitable to control microorganisms caused for diseases and it can be used naturally in human and veterinary healthcare systems.

\section{REFERENCES}

Abedini, A., Roumy, V., Mahieux, S., Biabiany, M., Standaert-Vitse. A. Rivière, C., Sahpaz, S., Bailleul, F., Neut, C., \& Hennebelle, T. (2013). Rosmarinic acid and its methyl ester as antimicrobial components of the hydromethanolic extract of Hyptis atrorubens Poit. (Lamiaceae). Evidence-Based Complementary and Alternative Medicine, 2013, 604536. https://doi.org/10.1155/2013/604536

Abreu, A.C., McBain, A.J., \& Simoes, M. (2012). Plants as sources of new antimicrobials and resistance-modifying agents. Natural Product Reports, 29(9), 1007-1021. https://doi.org/10.1039/C2NP20035J

Akhtar, F., Bashir, M., Baig, W., Zahoor, F., Shujaat, N., Humayun, E., Jamshaid, B., Hayat, A., Rehman, M.M., Jadoon, M.A., Abdulmalik, A., Ullah, Z., Gul, S., Mallick, M.A., \& ul Haq, Q.I. (2016). In vitro antibacterial activity of Spinacia oleracea and Melilotus indicus used in Pakistani folk medicines against some specific bacterial strains. IOSR Journal of Pharmacy and Biological Sciences, 11(1), 77-84. https://doi.org/10.9790/3008-11137784

Al-Snafi, A.E. (2020). Chemical Constituents and Pharmacological Effects of Melilotus officinalis- A Review. IOSR Journal of Pharmacy, 10(1), 26-36.

Annapurna, J., Chowdary, I.P., Lalitha, G., Ramakrishna, S.V., \& lyengar, D.S. (2004). Antimicrobial activity of Euphorbia nivulia leaf extract. Pharmaceutical Biology, 42(2), 91-93. http://dx.doi. org/10.1080/13880200490510658

Athanassiadis, B., Abbott, P. V., George, N., \& Walsh, L. J. (2009). An in vitro study of the antimicrobial activity of some endodontic medicaments and their bases using an agar well diffusion assay. Australian Dental Journal, 54(2), 141-146. https://doi.org/10.1111/j.18347819.2009.01107.x

Burt, S. (2004). Essential oils: their antibacterial properties and potential application in foods: A review. International Journal of Food Microbiology, 94(3), 223-253. https://doi.org/10.1016/j. ijfoodmicro.2004.03.022

Dhivya, S., \& Kalaichelvi, K. (2017). Phytochemical studies and gas chromatographymass spectrometry analysis of Sarcostemma brevistigma Wight \& Arn. Asian Journal of Pharmaceutical and Clinical 
Research, 10(3), 462-466. http://dx.doi.org/10.22159/ajpcr.2017. v10i3.16538

Feng, W. S., Gao, L., \& Zheng, X. K. (2010). A new lathyrane diterpene glycoside from Euphorbia helioscopia L. Chinese Chemical Letters, 21, 191-193. https://doi.org/10.1016/j.cclet.2009.10.002

Gill, A. O., \& Holley, R. A. (2006). Disruption of Escherichia coli, Listeria monocytogenes and Lactobacillus sakei cellular membranes by plant oil aromatics. International Journal of Food Microbiology, 108, 1-9. https://doi.org/10.1016/j.ijfoodmicro.2005.10.009

Gupta, R., \& Gupta, J. (2019). Investigation of antimicrobial activity of Euphorbia hirta leaves. International Journal of Life science and Pharma Research, 9(3), 32-37. http://dx.doi.org/10.22376/ijpbs/ Ipr.2019.9.3.P32-37

Izzo, A. A., Di Carlo, G., Biscardi, D., De Fusco, R., Mascolo, N., Borrelli, F., Capasso, F., Fasulo, M. P., \& Autore, G. (1995). Biological screening of Italian medicinal plants for antibacterial activity. Phytotherapy Research, 9(4), 281-286. https://doi.org/10.1002/ptr.2650090410

Jafri, S. M. H., \& El-Gadi, A. (1980). Flora of Libya. Vol 86, Department of Botany, El-Faateh University, Tripoli.

Jafri, S. M. H., \& El-Gadi, A. (1982). Flora of Libya. Vol 89, Department of Botany, El-Faateh University, Tripoli.

Janssen, A. M., Scheffer, J. J. C., \& Svendsen, A. B. (1987). Antimicrobial activity of essential oils: a 1976-1986 literature review. Aspects of the test methods. Planta Medica, 53(05), 395-398. https://doi. org/10.1055/s-2006-962755

Kirtikar, K. R., \& Basu, B. D. (1991). Indian Medicinal Plants (Vol. 3, $2^{\text {nd }}$ Eds.), Periodical Experts Books Agency: New Delhi.

Kubo, I., Muroi, H., Himejima, M., Yamagiwa, Y., Mera, H., Tokushima, K., Ohta, S. \& Kamikawa, T. (1993). Structure-antibacterial activity relationships of anacardic acids. Journal of Agricultural and Food Chemistry, 41(6), 1016-1019. https://doi.org/10.1021/jf00030a036

Lin, J., Opoku, A. R., Geheeb-Keller, M., Hutchings, A. D., Terblanche, S. E., Jäger, A. K., \& van Staden, J. (1999). Preliminary screening of some traditional zulu medicinal plants for anti-inflammatory and antimicrobial activities. Journal of Ethnopharmacology, 68(1-3), 267-274. https://doi.org/10.1016/S0378-8741(99)00130-0

Lone, B. A., Bandh, S. A., Chishti, M. Z., Bhat, F. A., Tak, H., \& Nisa, H. (2013). Anthelmintic and antimicrobial activity of methanolic and aqueous extracts of Euphorbia helioscopia L. Tropical Animal Health and Production, 45(3), 743-749. https://doi.org/10.1007/s11250-0120283-1

Mohammadi, S., Asgary, V., Shandiz, S. A. S., Heidari, E., Jozaghkar, H., Cohan, R. A., \& Mirzaie, A. (2015). Antimicrobial activity of methanolic root extracts of Euphorbia condylocarpa against pathogenic bacteria.
Advanced Studies in Biology, 7(2), 55-64. https://doi.org/10.12988/ asb.2015.41049

Mostafa, A. A., Al-Askar, A. A., Almaary, K. S., Dawoud, T. M., Sholkamy, E. N., \& Bakri, M. M. (2018). Antimicrobial activity of some plant extracts against bacterial strains causing food poisoning diseases. Saudi Journal of Biological Sciences, 25(2), 361-366. https://doi.org/10.1016/j.sjbs.2017.02.004

Naz, R., Ayub, H., Nawaz, S., Islam, Z. U., Yasmin, T., Bano, A., Wakeel, A. Zia, S., \& Roberts, T. H. (2017). Antimicrobial activity, toxicity and antiinflammatory potential of methanolic extracts of four ethnomedicinal plant species from Punjab. Pakistan. BMC Complementary and Alternative Medicine, 17(1), 1-13. https://doi.org/10.1186/s12906017-1815-z

Scalbert, A. (1991). Antimicrobial properties of tannins. Phytochemistry, 30(12), 3875-83. https://doi.org/10.1016/0031-9422(91)83426-L

Schapoval, E. E. S., Silveira, S. M., Miranda, M. L., Alice, C. B., \& Henriques, A. T. (1994). Evaluation of some pharmacological activities of Eugenia uniflora L. Journal of Ethnopharmacology, 44(3), 137-142. https://doi. org/10.1016/0378-8741(94)01178-8

Singh, G., \& Kumar, P. ( 2013). Phytochemical study and screening for antimicrobial activity of flavonoids of Euphorbia hirta. International Journal of Applied and Basic Medical Research, 3(2), 111. https:// doi.org/10.4103/2229-516X.117082

Sisay, M., Bussa, N., Gashaw, T., \& Mengistu, G. (2019). Investigating in vitro antibacterial activities of medicinal plants having folkloric repute in Ethiopian traditional medicine. Journal of Evidence-Based Integrative Medicine, 24, 1-9. https://doi.org/10.1177/2515690X19886276

Sonju, J. J., Islam, F., Sutradhar, K., \& Akter, T. (2017). Analysis of phytochemical, antioxidant and microbial property of various extracts of the plant Melilotus indica. World Journal of Pharmaceutical Research, 6(4), 129-147. https://doi.org/10.20959/wjpr20174-8050

Surapuram, V., Setzer, W. N., McFeeters, R. L., \& McFeeters, H. (2014). Antifungal activity of plant extracts against Aspergillus niger and Rhizopus stolonifer. Natural Product Communications, 9(11), 1603 1605. https://doi.org/10.1177/1934578X1400901118

Teh, C. H., Nazni, W. A., Nurulhusna, A. B., Norazah, A., \& Lee, H. L. (2017). Determination of antibacterial activity and minimum inhibitory concentration of larval extract of flyvia resazurin-based turbidometric assay. BMC Microbiology, 17(36), 1-8. https://doi.org/10.1186/ s12866-017-0936-3

Valgas, C., Souza, S. M. D., Smânia, E. F., \& Smânia, Jr. A. (2007). Screening methods to determine antibacterial activity of natural products. Brazilian Journal of Microbiology 38(2), 369-380. http://dx.doi. org/10.1590/S1517-83822007000200034 